\title{
ANALISIS PEMAHAMAN KONSEP PESERTA DIDIK DALAM MENYELESAIKAN SOAL-SOAL FISIKA KELAS X MIA SMA NEGERI 3 SOPPENG
}

\author{
${ }^{1)}$ Dedi Riwanto, ${ }^{2)}$ Aisyah Azis, ${ }^{3)}$ Kaharuddin Arafah \\ Universitas Negeri Makassar \\ Kampus UNM Parangtambung Jln. Daeng Tata Raya, Makassar, 90224 \\ ${ }^{1)}$ e-mail : dediriwantoidris@gmail.com
}

\begin{abstract}
Abstrak. Analisis Pemahaman Konsep Peserta Didik Dalam Menyelesaikan Soal-Soal Fisika Kelas X Mia Sma Negeri 3 Soppeng. Penelitian ini adalah penelitian Kuantitatif deskriptif menggunakan desain Survey yang bertujuan untuk mengetahui pemahaman konsep fisika peserta didik kelas X MIA SMA Negeri 3 Soppeng pada materi getaran harmonis. Subjek penelitian adalah kelas X MIA 3 sebanyak 21 siswa dan kelas X MIA 4 sebanyak 19 siswa di SMAN 3 Soppeng. Data hasil penelitian diperoleh dengan memberikan tes pemahaman konsep berupa post tes dalam bentuk pilihan ganda. Data dianalisis secara statistik deskriptif, diperoleh persentase pemahaman konsep setiap indikator secara berturut-turut adalah menafsirkan 75\%, mencontohkan 73\%, mengklasifikasikan 26\%, membandingkan 14\%, dan menjelaskan $61 \%$. Berdasrkan hal ini dapat disimpulkan bahwa pemahaman konsep fisika kelas X MIA SMA Negeri 3 Soppeng yang paling dominan adalah indikator menafsirkan dan berada pada kategori tinggi sedangkan yang sangat tidak dominan adalah indikator membandingkan dan berada pada kategori sangat rendah. Faktor yang menyebabkan pemahaman konsep peserta didik rendah yaitu, kurangnya minat dan motivasi peserta didik untuk mengulang materi yang telah dipelajari, terbiasa belajar dengan menghafal rumus, belum mampu memanipulasi persamaan yang mengandung tiga variabel dan kurang teliti dalam memahami soal.
\end{abstract}

Kata kunci : Pemahaman konsep fisika, getaran harmonis.

\begin{abstract}
Analysis Of Understanding Concept Of Students In Completing Physics Problems Of Class X Mia Sma Negeri 3 Soppeng. This research is a descriptive quantitative research using survey design which aims to determine the understanding of the physics concepts of students of class X MIA SMA Negeri 3 Soppeng on harmonic vibration material. The subjects of the study were class X MIA 3 as many as 21 students and class X MIA 4 as many as 19 students in SMA 3 Soppeng. The result data is obtained by giving concept comprehension test in the form of post test in the form of multiple choice. Data were analyzed descriptively statistically, obtained the percentage of understanding of the concept of each indicator in a row is interpreting 75\%, exemplifying 73\%, classifying 26\%, comparing $14 \%$, and explaining $61 \%$. Based on this, it can be concluded that the understanding of the physical concept of class X MIA SMA Negeri 3 Soppeng is the indicator of interpreting and being in the high category while the very non-dominant indicator is comparing and in the very low category. Factors that cause students' understanding of the concept are low, namely the lack of interest and motivation of students to repeat the material that has been learned, accustomed to learning by memorizing formulas, not being able to manipulate equations that contain three variables and less thorough in understanding the problem.
\end{abstract}

Keywords : Understanding of physics concept, harmonic vibration.

\section{PENDAHULUAN}

Seiring dengan berkembannya ilmu pengetahuan dan teknologi yang membawa perubahan bagi kehidupan manusia maka pendidikan disekolah adalah suatu kebutuhan yang sangat mutlak yang harus dipenuhi oleh setiap manusia. Melalui pendidikan manusia akan memperoleh pengetahuan dan dengan pengetahuannya itulah manusia dapat membangun hidupnya yang lebih baik. Hal ini dikarenakan pendidikan dapat mengubah pola pikir seseorang untuk mengoptimalkan kecerdasannya

Fisika sangat memegang peranan penting dalam perkembangan ilmu pengetahuan dan teknologi. Hal ini dikarenakan fisika merupakan 
cabang ilmu pengetahuan yang mempelajari segala fenomena yang terjadi di alam semesta.

Kemampuan pemahaman peserta didik dapat dilihat dari hasil tes dalam menyelesaikan soal, salah satunya dalam pembelajaran fisika. Peserta didik harus mampu mengembangkan kemampuan berfikirnya dan tidak hanya sekedar menghafal pelajaran, tetapi dalam pembelajaran peserta didik mampu memahami konsep-konsep yang diajarkan sehingga peserta didik dapat memecahkan dan mencari solusi dari suatu persoalan. Seperti kita ketahui bahwa fisika merupakan ilmu empiris, sehingga untuk menyelesaikan soal fisikanya peserta didik terlebih dahulu harus memahami konsep dari materi yang dipelajari. Hal ini sesuai dengan yang dikemukakan oleh Sudrajad (2009) fisika dibangun berdasarkan pengalaman empiris, dimana konsep-konsep diformulasikan berdasarkan fakta dan data hasil pengamatan terhadap gejala-gejala yang ada di kehidupan sehari-hari.. Ketika kita ingin mempelajari fisika hal yang paling utama adalah memahami konsep fisika terlebih dahulu. Pernyataan di atas sesuai dengan pendapat Widodo (2006), yaitu langkah awal yang paling tepat untuk mempelajari fisika adalah memahami konsepnya terlebih dahulu. Konsep-konsep pembelajaran tersusun secara sistematis. Sehingga diperlukan penguasaan konsep dalam setiap materi pelajaran sebelum melanjutkan ke materi selanjutnya. Konsep yang lebih awal diajarkan akan menjadi dasar bagai pengembangan konsep-konsep selanjutnya.

Berdasarkan hasil penelitian terdahulu yang telah dilakukan oleh Suhartin, dkk (2017) tentang Analisis Pemahaman Konsep Spektrum Cahaya Pada Siswa SMA Negeri 2 Jember Kelas XII. Berdasarkan hasil penelitiannya diperoleh bahwa tingkat pemahaman konsep siswa pada materi spektrum cahaya tergolong baik.

Selain itu, penelitian yang dilakukan oleh Puspitasari, dkk (2017) tentang Analisis Pemahaman Konsep Tentang Elastisitas di kelas XI SMA. Adapun hasil penelitiannya yaitu, pemahaman konsep siswa paling baik terdapat pada konsep pegas yaitu pada indikator menghitung konstanta pegas yang disertai grafik hubungan antara gaya dan pertambahan panjang.

Mata pelajaran fisika merupakan mata pelajaran yang tergolong sulit dan kurang diminati oleh peserta didik. Hal ini terlihat dari hasil observasi di SMA Negeri 3 Soppeng. Berdasarkan hasil observasi dengan mewawancarai lansung beberapa peserta didik terhadap mata pelajaran fisika. Mereka mengatakan bahwa fisika itu sangat menantang dan menarik untuk dipelajari dan ada juga yang menilai mata pelajaran fisika itu sangat sulit, tidak menarik dan membosakan karena terlau banyak rumus dan hitung-hitungannya sehingga susah untuk dipahami. Berdasarkan hasil wawancara guru fisika kelas $\mathrm{X}$ ia mengatakan bahwa pada saat diberikan ujian banyak peserta didik yang tidak mencapai Kriteria Ketuntasan Minimal (KKM) hal ini dikarenakan sebagian besar peserta didik hanya mengandalkan kemampuan hafalannya saja. Ketika diberikan soal yang berbeda mereka kesulitan untuk mengerjakannya. Oleh karena itu, pemahaman konsep peserta didik sangatlah penting untuk dapat

menyelesaikan soal-soal fisika. Jika peserta didik belum memahami konsep. maka peserta didik akan mengalami kesulitan dalam menyelesaikan soal-soal fisika.

\section{METODE}

Penelitian ini merupakan penelitian deskriptif kuantitatif. Subjek penelitian yaitu peserta didik kelas X MIA SMA Negeri 3 Soppeng yang berjumlah 40 orang peserta didik. Penelitian ini dilaksanakan pada semester genap tahun ajaran 2017/2018 (23 April-30 Mei 2018). Peneltian ini bertempat di SMA Negeri 3 Soppeng. Adapun variabel yang diteliti adalah pemahaman konsep fisika. 
Instrumen yang digunakan pada penelitian ini adalah instrumen tes pemahaman konsep fisika berupa tes pilihan ganda. Sebelum digunakan, digunakan, soal yang telah disusun terlebih dahulu divalidasi oleh dua seorang pakar kemudian dilakukan uji validitas dan reliabilitas dengan menggunakan persamaan koefisien korelasi biserial, Gutmann dan Kuder-Richarson, formula KR20 (Yusuf, 2014). Kriteria pengujiannya adalah jika $\gamma_{\text {pbis }} \geq r_{\text {tabel }}$ maka item dinyatakan valid dan jika $\gamma_{\text {pbis }}<r_{\text {tabel }}$ maka item dinyatakan drop.
Data yang diperoleh pada penelitian ini dianalisis secara deskriptif. Analisis deskriptif ini ditampilkan dalam bentuk persentase skor ratarata peserta didik untuk setiap butir soal dan persentase skor rata-rata peserta didik untuk setiap indikator pemahaman konsep.

\section{HASIL DAN PEMBAHASAN}

Berdasarkan hasil analisis statistik deskriptif persentase skor rata-rata pemahaman konsep fisika kelas X MIA SMA Negeri 3 Soppeng dapat dilihat pada tabel berikut.

Tabel 1. Persentase Skor Rata-rata Tes Pemahaman Konsep Peserta Didik Pada Indikator Menafsirkan

\begin{tabular}{cccc}
\hline Nomor Soal & $\begin{array}{c}\text { Indikator } \\
\text { Pemahaman } \\
\text { Konsep }\end{array}$ & $\begin{array}{c}\text { Persentase Skor Rata-Rata } \\
\text { Pemahaman Konsep (\%) }\end{array}$ & $\begin{array}{c}\text { Kategori Pemahaman } \\
\text { Konsep }\end{array}$ \\
$\mathbf{1}$ & & 88 & Sangat Tinggi \\
$\mathbf{3}$ & Menafsirkan & 90 & Sangat Tinggi \\
$\mathbf{4}$ & & 90 & Sangat Tinggi \\
$\mathbf{5}$ & & 98 & Sangat Tinggi \\
$\mathbf{6}$ & & 85 & Sangat Tinggi \\
$\mathbf{7}$ & & 65 & Tinggi \\
\hline
\end{tabular}

Berdasarkan Tabel 1 di atas menunjukkan bahwa persentase skor rata-rata peserta didik kelas X MIA SMA Negeri 3 Soppeng tiap butir soal pada indikator menafsirkan. Peserta didik yang banyak menjawab dengan benar adalah pada soal nomor 4 dan soal nomor 5 dengan persentase 98\% berada pada kategori sangat tinggi Sedangkan persentase skor rata-rata peserta didik yang sedikit menjawab benar adalah pada nomor 7 dengan persentase $13 \%$ berada pada kategori sangat rendah. 
Tabel 2. Persentase Skor Rata-rata Tes Pemahaman Konsep Peserta Didik Pada Indikator Mencontohkan

\begin{tabular}{cccc}
\hline Nomor Soal & $\begin{array}{c}\text { Indikator Pemahaman } \\
\text { Konsep }\end{array}$ & $\begin{array}{c}\text { Persentase Skor Rata- } \\
\text { Rata Pemahaman } \\
\text { Konsep (\%) }\end{array}$ & $\begin{array}{c}\text { Kategori } \\
\text { Pemahaman } \\
\text { Konsep }\end{array}$ \\
\hline $\mathbf{8}$ & & 65 & Tinggi \\
$\mathbf{9}$ & Mencontohkan & 48 & Sedang \\
$\mathbf{1 0}$ & & 80 & Tinggi \\
$\mathbf{1 1}$ & & 98 & Sangat Tinggi \\
\hline
\end{tabular}

Berdasarkan Tabel 2 di atas menunjukkan bahwa persentase skor rata-rata pemahaman konsep peserta didik kelas X MIA SMA Negeri 3 Soppeng tiap butir soal pada indikator mencontohkan yang paling banyak dijawab dengan benar oleh peserta didik adalah nomor soal 11 dengan persentase $98 \%$ berada pada kategori sangat tinggi sedangkan persentase skor rata-rata peserta didik yang sedikit menjawab benar adalah pada soal nomor 9 dengan persentase $48 \%$ berada pada kategori sedang.

Tabel 3. Persentase Skor Rata-rata Tes Pemahaman Konsep Peserta Didik Pada Indikator Mengklasifikasikan

\begin{tabular}{cccc}
\hline Nomor Soal & $\begin{array}{c}\text { Indikator Pemahaman } \\
\text { Konsep }\end{array}$ & $\begin{array}{c}\text { Persentase Skor Rata- } \\
\text { Rata Pemahaman } \\
\text { Konsep (\%) }\end{array}$ & $\begin{array}{c}\text { Kategori } \\
\text { Pemahaman } \\
\text { Konsep }\end{array}$ \\
\hline $\mathbf{1 2}$ & Mengklasifikasikan & 45 & Sedang \\
$\mathbf{1 3}$ & & 20 & Sangat Rendah \\
$\mathbf{1 4}$ & & 13 & Sangat Rendah \\
\hline
\end{tabular}

Berdasarkan Tabel 3 di atas menunjukkan bahwa persentase skor rata-rata peserta didik kelas X MIA SMA Negeri 3 Soppeng tiap butir soal pada indikator mengklasifikasikan yang paling banyak dijawab benar adalah soal nomor
12 dengan persentase $45 \%$ berada pada kategori sedang. Sedangkan persentase skor rata-rata peserta didik yang sedikit menjawab benar adalah soal nomor 14 dengan persentase $13 \%$ berada pada kategori sangat rendah.

Tabel 4. Persentase Skor Rata-rata Tes Pemahaman Konsep Peserta Didik Pada Indikator Membandingkan

\begin{tabular}{cccc}
\hline Nomor Soal & $\begin{array}{c}\text { Indikator Pemahaman } \\
\text { Konsep }\end{array}$ & $\begin{array}{c}\text { Persentase Skor Rata- } \\
\text { Rata Pemahaman Konsep }\end{array}$ & $\begin{array}{c}\text { Kategori } \\
\text { Pemahaman } \\
\text { Konsep }\end{array}$ \\
\hline $\mathbf{1 5}$ & Membandingkan & 10 & Sangat Rendah \\
$\mathbf{1 6}$ & & 18 & Sangat Rendah \\
\hline
\end{tabular}

Berdasarkan Tabel 4 di atas menunjukkan bahwa persentase skor rata-rata peserta didik kelas X MIA SMA Negeri 3 Soppeng tiap butir soal pada indikator membandingkan, yaitu soal 
nomor 16 lebih banyak dijawab dengan benar oleh peserta didik dibandingkan dengan soal nomor 15 dengan persentase $18 \%$ dan $10 \%$ berada pada kategori sangat rendah.

Tabel 5. Persentase Skor Rata-rata Tes Pemahaman Konsep Peserta Didik Pada Indikator Menjelaskan

\begin{tabular}{cccc}
\hline Nomor Soal & $\begin{array}{c}\text { Indikator Pemahaman } \\
\text { Konsep }\end{array}$ & $\begin{array}{c}\text { Persentase Skor Rata-Rata } \\
\text { Pemahaman Konsep (\%) }\end{array}$ & $\begin{array}{c}\text { Kategori } \\
\text { Pemahaman } \\
\text { Konsep }\end{array}$ \\
\hline $\mathbf{1 7}$ & Menjelaskan & 63 & Tinggi \\
$\mathbf{1 8}$ & & 60 & Sedang \\
\hline
\end{tabular}

Berdasarkan Tabel 5 di atas menunjukkan bahwa persentase skor rata-rata peserta didik kelas X MIA SMA Negeri 3 Soppeng tiap butir soal pada indikator menjelaskan yang paling banyak dijawab benar adalah soal nomor 17 dengan persentase $63 \%$ berada pada kategori tinggi. Sedangkan persentase skor rata-rata peserta didik yang sedikit menjawab benar adalah soal nomor 18 dengan persentase $60 \%$ berada pada kategori sedang.

Kriteria skor hasil perolehan tiap indikator pemahaman konsep fisika kelas X MIA SMA Negeri 3 Soppeng yang disesuaikan dengan kriteria interpretasi skor pemahaman konsep fisika berdasarkan adopsi oleh Riduwan (2011) sebagai berikut.

Tabel 6 Persentase tiap Indikator Pemahaman Konsep Fisika Kelas X MIA SMA Negeri 3 Soppeng

\begin{tabular}{ccc}
\hline Indikator & Persentase (\%) & Kategori \\
\hline Menafsirkan & 75 & Tinggi \\
Mencontohkan & 73 & Tinggi \\
Mengklasifikasikan & 26 & Rendah \\
Membandingkan & 14 & Sangat Rendah \\
Menjelaskan & 61 & Tinggi \\
\hline
\end{tabular}

Berdasarkan Tabel 6 di atas menunjukkan bahwa persentase rata-rata skor pemahaman konsep peserta didik kelas X MIA SMA Negeri 3 Soppeng untuk setiap indikator pemahaman konsep. Indikator menafsirkan memiliki persentase paling tinggi yaitu $75 \%$ berada pada kategori tinggi. Kemudian indikator mencontohkan memiliki persentase sebesar $73 \%$ berada pada kategori tinggi. Pada indikator mejelaskan memiliki persentase sebesar $61 \%$ berada pada kategori tinggi. Pada indikator mengklasifikasikan memiliki persentase sebesar $26 \%$ berada pada kategori rendah. Sedangkan indikator membandingkan merupakan indikator yang memiliki persentase yang sangat rendah yaitu $14 \%$.

Berdasarkan hasil analisis penelitian pada indikator menafsirkan pemahaman konsep fisika peserta didik berada pada kategori tinggi. Pada soal nomor 1 diperoleh 35 peserta didik yang menjawab benar dengan memilih jawaban $C$, sementara 5 peserta didik memilih jawaban B. Pada soal nomor 2 diperoleh 36 peserta didik yang menjawab benar dengan memilih jawaban $\mathrm{C}$, sementara yang menjawab A, B dan D dipilih sebanyak 1, 1 dan 2. Pada soal nomor 3 diperoleh 33 peserta didik yang menjawab benar dengan memilih pilihan jawaban A, sementara yang menjawab $\mathrm{B}$ dan $\mathrm{C}$ dipilih sebanyak 1 dan 3 peserta didik. Pada soal nomor 4 diperoleh 39 
peserta didik yang menjawab benar dengan memilih pilihan jawaban $\mathrm{D}$, sementara 1 orang peserta didik memilih jawaban A. Pada soal nomor 5 diperoleh 34 peserta didik menjawab benar dengan memilih jawaban $\mathrm{C}$, sementara 5 peserta didik menjawab B dan 1 peserta didik menjawab A. Pada soal nomor 6 diperoleh 27 peserta didik yang menjawab benar dengan memilih jawaban E, sementara yang menjawab A, B dan $\mathrm{C}$ dipilih sebanyak 9, 3 dan 1. Pada soal nomor 7 diperoleh 5 peserta didik yang menjawab benar dengan memilih jawaban E, sementara 30 peserta didik memilih pilihan $\mathrm{D}$, yang menjawab A dan B dipilih sebanyak 3 dan 2 peserta didik. Hal ini menunjukkan bahwa sebagian besar peserta didik sudah dapat menafsirkan grafik atau tabel. Hal tersebut sejalan dengan hasil penelitian yang dilakukan oleh Hasbullah, dkk (2017) dimana kemampuan interpretasi grafik dengan menggunakan pendekatan multi-repsentasi dapat meningkatkan pemahaman siswa. Kemampuan peserta didik dalam memahami grafik atau tabel sangatlah penting karena ketika melakukan suatu percobaan terutama dibidang fisika peserta didik harus mampu menyajikan data-data yang diperoleh dari hasil percobaan kedalam bentuk grafik. Adapun pada soal nomor 7 peserta didik keliru dalam memilih jawaban, atau tergesa-gesa pada saat mengerjakan soal. Hal ini sesuai dengan hasil penelitian yang dilakukan oleh Suroso (2016) bahwa faktor yang menyebabkan peserta didik melakukan kesalahan pada saat diberikan tes yaitu, siswa terburu-buru sehingga kurang teliti dalam memahami soal. Siswa juga salah strategi karena langkah penyelesaian soal yang tidak tepat.

Berdasarkan hasil analisis penelitian pada indikator mencontohkan pemahaman konsep fisika berada pada kategori tinggi. Pada soal nomor 8 diperoleh 26 peserta didik menjawab dengan benar memilih pilihan $\mathrm{D}$, sementara yang menjawab A, B, C dan E dipilih sebanyak 1, 5, 7, dan 1 peserta didik. Pada soal nomor 9 diperoleh
19 peserta didik menjawab dengan benar memilih pilihan A, sementara yang menjawab B, D dan E dipilih sebanyak 5, 3 dan 13 peserta didik. Pada soal nomor 10 diperoleh 32 peserta didik menjawab dengan benar memilih pilihan $\mathrm{E}$, sementara yang menjawab A, B dan D dipilih sebanyak 3, 2 dan 2 peserta didik. Pada soal nomor 11 diperoleh 39 peserta didik menjawab dengan benar memilih pilihan A, sementara 1 peserta didk memilih pilihan D. Hal ini menunjukkan bahwa sebagian besar peserta didik sudah dapat mengaplikasikan penerapan getaran harmonis dalam kehidupan-sehari-hari. Adapun penelitian yang dilakukan oleh Husaian (2016) dimana kemampuan pemahaman konsep peserta didik pada indikator mencontohkan peserta didik sedikit mampu mengerjakan soal-soal dalam hal menemukan contoh kasus menggambarkan dari suatu konsep atau prinsip.

Berdasarkan hasil analisis penelitian pada indikator mengklasifikasikan pemahaman konsep fisika berada pada kategori rendah. Pada soal nomor 12 diperoleh 18 peserta didik yang menjawab benar dengan memilih jawaban $\mathrm{B}$, sementara yang menjawab A, C, D dan E, dipilih sebanyak 18, 3, 2 dan 6 peserta didik. Pada soal nomor 13 diperoleh 8 peserta didik yang menjawab benar dengan memilih jawaban $\mathrm{E}$, sementara yang menjawab A, B, C dan D, dipilih sebanyak 18, 5, 2 dan 7 peserta didik. Pada soal nomor 14 diperoleh 5 peserta didik yang menjawab benar dengan memilih jawaban $\mathrm{E}$, sementara yang menjawab $\mathrm{A}, \mathrm{B}, \mathrm{C}$ dan $\mathrm{D}$, dipilih sebanyak 4, 15, 13 dan 3 peserta didik. Hal ini menunjukkan bahwa kemampuan pemahaman konsep peserta didik pada indikator mengklasifikasikan masih kurang. Hal ini disebabkan karena peserta didik belum mampu mengkategorikan atau mengelompokkan polapola yang sesuai dengan konsep atau peserta didik kurang memahami materi dan keliru pada saat memilih jawaban. Hal sejalan dengan hasil penelitian yang dilakukan oleh Prihartiningsih, 
dkk (2018) bahwa sebagian besar peserta didik dapat membuat pengelompokkan tetapi tidak dapat menyebutkan dasar yang digunakan untuk mengelompokkan. Hal ini mengindikasikan bahwa mereka mampu memahami soal tetapi tidak menggunakan konsep yang benar dalam menyelesaikan masalah. Hal serupa dikemukakan oleh Suraji, dkk (2018) ada beberapa peserta didik keliru dalam memahami soal sehingga mereka bingung menggunakan konsep yang mana seharusnya digunakan. Hal menyebabkan peserta didik tidak memahami soal dengan baik.

Berdasarkan hasil analisis penelitian pada indikator membandingkan pemahaman konsep fisika berada pada kategori sangat rendah. Pada soal nomor 15 diperoleh 4 peserta didik yang menjawab benar dengan memilih jawaban A, sementara yang menjawab B, C, D dan E dipilih sebanyak 8, 3, 9, dan 16. Pada soal nomor 16 diperoleh 7 peserta didik yang menjawab benar dengan memilih jawaban E, sementara yang menjawab A, B, C dan D dipilih sebanyak 4, 7, 21, dan 1. Hal ini menunjukkan bahwa kemampuan pemahaman konsep pada indikator membandingkan sangat kurang dapat dilihat dari hasil analisis. Sebagian besar peserta didik belum dapat mendeteksi persamaan atau belum dapat memanipulasi dua variabel atau lebih. Peserta didik salah dalam memasukkan nilai pada setiap variabel dan salah dalam melakukan opersi matematiknya. Selain itu, peserta didik hanya mengandalkan kemampuan hafalan saja sehingga ketika diberikan soal yang berbeda mereka kesulitan untuk mengerjakannya. Hal tersebut sejalan dengan hasil penelitian yang dilakukan oleh Suryaningsih, dkk (2015) bahwa pemahaman konsep peserta didik pada indikator menafsirkan masih tergolong rendah. Penyebab kesalahan yang dilakukan peserta didik yaitu kesalahan terjemahan yang disebabkan peserta didik tidak memahami data-data yang disebutkan dalam soal, tidak memahami simbol-simbol fisika untuk data-data yang disebutkan dalam soal, kurang teliti dalam melakukan operasi hitung (Sari, Surantoro, \& Ekawati, 2013).

Berdasarkan hasil analisis penelitian pada indikator menjelaskan pemahaman konsep fisika berada pada kategori tinggi. Pada soal nomor 17 diperoleh 25 peserta didik yang menjawab benar dengan memilih jawaban $C$, sementara yang menjawab A, B, D dan E dipilih sebanyak 7, 4, 2, dan 1. Pada soal nomor 18 diperoleh 24 peserta didik yang menjawab benar dengan memilih jawaban E, sementara yang menjawab A, C dan D dipilih sebanyak 8, 3 dan 5. Hal ini menunjukkan bahwa sebagianbesar peserta didik sudah dapat mengungkapkan konsep-konsep yang bersifat teori. Hal ini sejalan dengan penelitian Trianggono (2017) yaitu kemampuan menjelaskan adalah kemampuan seseorang dalam membuat dan menggunakan model sebab akibar dalam sebuah sistem. Seseorang yang lancar dalam membuat hubungan antara satu konsep dengan konsep lainnya akan memiliki kemampuan menjelaskan yang lebih baik dibandingkan dengan yang kurang lancar.

Berdasarkan analisis nomor 7, 13, 14, 15 dan 16 yang menyebabkan terjadinya pemahaman konsep fiska peserta didik kurang adalah kurangnya motivasi dan minat peserta didik untuk mengulang materi yang telah dipelajarinya. Hal ini sesuai dengan hasil penelitian yang dilakukan oleh Nofitasari, dkk (2017) bahwa faktor-faktor yang menyebabkan peserta didik kurang memahami materi yaitu kurangnya minat dan motivasi belajar peserta didik, kurangnya variasi media dan metode pembelajaran. Peserta didik terbiasa belajar dengan menghafal rumus sehingga kesulitan dalam memahami konsep yang baru diajarkan. Karena belajar dengan menghafal tidak akan bermakna dan bersifat sementara. Peserta didik terburu-buru sehingga kurang teliti memahami soal. Hal ini sejalan dengan hasil penelitian yang dilakukan oleh Efrilia (2016) bahwa penyebab kesalahan yang dilakukan oleh peserta didik yaitu tidak 
memahami simbol fisika dari data-data yang disebutkan pada soal, salah mengartikan maksud soal, kurang teliti dalam membaca serta memahami maksud soal. Suasana kelas yang terlalu ribut yang menyebabkan sebagian besar peserta didik kurang memperhatikan pendidik pada saat menjelaskan.

Berdasarkan hasil pembahasan ini maka seharusnya pendidik menyampaikan konsep dasar dari setiap materi dalam mengajar dan tidak hanya menyampaikan rumus yang cenderung membuat peserta didik menghafal sehingga mudah lupa, pendidik sebaiknya melakukan demonstrasi atau praktikum langsung ketika menjelaskan agar peserta didik lebih termotivasi untuk belajar, sebaiknya pendidik merancang strategi pembelajaran yang bermakna, dan sebaiknya pendidik menunjukkan penerapan fisika dalam kehidupan sahari-hari.

Selain itu, peserta didik diharapkan mampu mengulangi kembali materi yang telah dipelajari, tidak mengandalkan kemampuan hafalannya, memperbanyak mengerjakan soal-soal latihan dan peserta didik diharapkan lebih teliti dalam membaca soal dan menghitung.

\section{SIMPULAN}

Berdasarkan hasil penelitian dan pembahasan maka dapat disimpulkan bahwa pemahaman konsep fisika kelas X MIA SMA Negeri 3 Soppeng tahun ajaran 2017/2018 pada materi getaran harmonis menunjukkan persentase pemahaman konsep yang paling dominan adalah indikator menafsirkan dan yang sangat tidak dominan adalah indikator membandingkan. Pada indikator menafsirkan pemahaman konsep peserta didik berada pada kategori tinggi di mana peserta didik sudah dapat menafsirkan tabel dan grafik, pada indikator mencontohkan pemahaman konsep peserta didik berada pada kategori tinggi, indikator menjelaskan berada pada kategori tinggi, sedangkan pada indikator mengklasifikasikan pemahaman konsep peserta didik berada pada kategori rendah dan pada indikator membandingkan berada pada kategori sangat rendah.

Ada beberapa faktor yang menyebabkan pemahaman konsep peserta didik rendah yaitu, kurangnya minat dan motivasi peserta didik untuk mengulang kembali materi yang telah diajarkan, peserta didik masih kesulitan utuk memanipulasi persamaan sederhana yang mengandung tiga variabel. Peserta didik terbiasa menghafal konsep sehingga ketika diberikan soal yang berbeda mereka kesulitan untuk mengerjakannya, peserta didik kurang memahami soal dan kondisi kelas yang tidak nyaman.

\section{DAFTAR RUJUKAN}

Efrilia, D. (2016). Analisis Kesalahan Siswa Dalam Menyelesaikan Soal Fisika Pada Materi Gerak Lurus di Kelas VII SMP Negeri Purwodadi Tahun Ajaran 2015/2016. Jurnal Pendidikan Fisika STKIP-PGRI Lubuklinggau. Vol. 1, No. 1: 7.

Husaian, M.S., Kendek, Y., \& Fihrin. (2016). Analisis Tingkat Pemahaman Konsep Fluida Statis dan Penerapannyan di Lingkungan Sekitar Pada Siswa SMA Negeri 2 Palu. Jurnal Pendidikan Fisika Tadulako (JPFT). Vol. 6, No.1: 26.

Hasbullah, \& Nazriana. L. (2017). Peningkatan Kemampuan Interpretasi Grafik Melalui Pendekatan Multi-representasi Pada Materi Gerak Lurus. Jurnal Seminar Nasional II USM (Universitas Serambi Mekkah). Vol.1: 117.

Nofitasari, I., Sihombing, Y. (2017). Deskripsi Kesulitan Belajar Peserta Didik dan Faktor Penyebabnya Dalam Memahami Listrik Dinamis Kelas X SMA Negeri 2 Bengkayang. Jurnal Penelitian Fisika dan Aplikasinya (JPFA). Vol. 7, No. 1: 49. 
Prihartiningsih, Zubaidah, S., \& Kusairi, S. 2016. Kemampuan Berpikir Kritis Siswa SMP Pada Materi Klasifikasi Mahluk Hidup. Jurnal Pros. Semnas Pend. IPA Pascasarjana UM. Vol. 1: 1059.

Puspitasari, D., Prastowo, S.H.B. \& Pribandono, T. (2017). Analisis Pemahaman Konsep Siswa Tentang Elastisitas Di Kelas XI SMA. Jurnal Pendidikan Fisika. Vol. 2: 4.

Riduwan. (2011). Dasar-Dasar Statistik . Bandung: Alfabeta.

Suryaningsih, H, Yani., A., \& Herman. (2015). Pengaruh Media Presentasi Berbasis Pendekatan Ilmiah Terhadap Pemahaman Konsep Fisika Pada Peserta Didik Kelas XI IPA SMA Negeri 10 Makassar. Jurnal Sains dan Pendidikan Fisika ( JSPF ). Vol. 1, No.3: 234.

Suroso. (2016). Analisis Kesalahan Siswa Dalam Mengerjakan Soal-soal Fisika Termodinamika Pada Siswa SMA Negei 1 Magetan. Jurnal Edukasi Matematika dan Sains. Vol.4, No.1: 14.

Suraji, Maimunah, \& Saragih, S. (2018). Analisis Kemampuan Pemahaman Konsep Matematis dan Kemampuan Pemecahan Masalah Matematis Siswa SMP Pada Materi Sistem Persamaan Linear Dua Variabel (SPDLV). Suska Journal of Mathematics Education. Vol. 4, No.1: 14.

Sari, D.M., Surantoro., \& Ekawati, E.Y. (2013). Analisis Kesalahan dalam Menyelesaikan Soal-Soal Materi Termodinamika Pada Siswa Sma. Jurnal Materi dan Pembelajaran Fisika. Vol. 3, No.1: 5.

Suhartin, Y,. Prastowo, S.H.B,. \& Trapsilo, T. (2017). Analisis Pemahaman Konsep Spektrum Cahaya Pada Siswa Sma Kelas XII. Jurnal Pendidikan Fisika. Vol. 2: 4.
Sudrajad, H. (2009). Pengembangan Perangkat Percobaan Konsep Rotasi Untuk Pembelajaran Fisika di Sma dan di Universitas. Jurnal Galiga Sains. Vol. 3, No. 2: 1 .

Trianggono, M.M. (2017). Analisis Kausalitas Pemahaman Konsep Dengan Kemampuan Berpikir Kreatif Siswa Pada Pemecahan MasalahFisika. Jurnal Pendidikan Fisika dan Keilmuan (JPFK). Vol. 3, No. 1: 8.

Widodo, Y. T. B. (2006). Brilliant Solution Cara Cerdas Mengerjakan Soal Fisika Mekanika untuk SMA/MA. Yogyakarta: Andi Offset.

Yusuf, M. (2014). Metode Penelitian (Kuantitatif, Kualitatif, dan Penelitian Gabungan). Jakarta: Prenadamedia Group. 